\title{
Most Prevalent Study Skills among Taiwanese High School Students with Reference to Gender
}

\author{
Abolfazl Shirban Sasi ${ }^{1}$, Toshinari Haga ${ }^{2}$ \\ ${ }^{1}$ Department of Foreign Languages, National Chiayi University, Taiwan \\ ${ }^{2}$ Department of Applied Foreign Languages, TransWorld University, Taiwan \\ Correspondence: Abolfazl Shirban Sasi, Department of Foreign Languages, National Chiayi University, Taiwan.
}

Received: March 2, 2020

doi:10.5430/wjel.v10n1p29
Accepted: March 23, $2020 \quad$ Online Published: March 26, 2020

URL: https://doi.org/10.5430/wjel.v10n1p29

\begin{abstract}
This study investigated Taiwanese high school students' study skills with reference to gender differences. 612 students (358 girls, and 254 boys) from six random high schools in Taiwan participated in this study. A 24-item questionnaire originally developed by University of Houston Clear Lake, Texas was adopted, abridged, and administered. The main focus of the questionnaire was on three study habits/skills constructs of "time management \& procrastination", "study aids \& note-taking", and "organizing \& processing information" (eight items each). A Pearson Chi-square test $(\alpha \leq .05)$ was used for each of the 24 items of the questionnaire. The results showed that Taiwanese high school boys and girls have very similar, an even sometimes identical, viewpoints towards study skills. The only significant difference observed in the data analysis in this study were items 1,5 , and 8 , suggesting that compared with girls, boys typically care more about time management. Moreover, and based on the rubrics devised by the original instrument developer, it was calculated that the highest difference between boys and girls was .61 "arriving at classes and other meetings on time", whereas the lowest difference was 0 for "maintaining a critical attitude during study - thinking before accepting or rejecting". Also, both girls and boys equally seemed to be strongest in "arriving at classes and other meetings on time" (item 1), and weakest in "having a system for marking textbooks" (item 14).
\end{abstract}

Keywords: comparison; gender; high school; rubrics; study habits

\section{Introduction}

The present paper intends to examine the study habits of the Taiwanese high school students. There is no doubt that students themselves, as well as parents, teachers, and education authorities can benefit more when knowing more precisely about the diverse list of study habits, so that they can think better and program wisely for adapting and maintaining good study habits, and refraining and preventing the bad ones. Moreover, a thorough investigation about potential differences and/or similarities among female and male students will definitely add insight to the existing situation and pave the road to more ideal developments.

\section{Review of Literature}

\subsection{Definition of Study Habits}

Scholars have defined study habits differently. For instance, study skills have been associated to certain behaviors such as preparing for exams (Purdue \& Hattie, 1999); doing homework, and conducting projects (Wagner, Schober, \& Spiel, 2008); and taking notes (Neri, 2007). Likewise, according to Ogbodo (2010), children are exposed to various experiences that impact their behavior. Thus, learning is a change in behavior. Such a change can be witnessed in their mental reasoning, physical growth, manipulative skills and growth of values and interests. The change might be easy or hard based on the home and school environment. Furthermore, several researchers have considered study skills as the most influential factors on academic achievement (Aquino, 2011; Gettinger \& Siebert, 2002; Jansen \& Suhre, 2010; Steele, 2010; Yu, 2011). Then, Putwain, Sander \& Larkin (2013) believe that qualities such as motivation, self-efficiency, ambitions, and perseverance are nonacademic aspects of study skills. Bajwa et al. (2011) assert that study habits include methods selected by students for private study, or the technique used to internalize a topic after class. There is also a general tendency to associate good habits of reading with students' academic performance. For example, Issa et al. (2012) emphasized that everyday reading activities in which students 
engage influence their studying skills and academic performance. Also, according to Palani (2012), reading habit is fundamental aspect for creating a literate society. Moreover, according to Ebele and Olofu (2017), good study habits typically include studying in a quiet place, studying regularly, taking notes of important content, turning off distracting devices like phones, having regular rests and breaks, listening to soft music while studying, focusing on personal learning styles, and prioritizing the difficult subjects first. Scott (2019) believes getting enough sleep and rest is a good study habit. Then, according to Grohol (2018), the key to effective studying is not cramming or studying longer, it rather is studying smarter. Similarly, Smith (2018) emphasizes that consistency is the key and once students start getting into good study habits, it will become a routine which they will be able to maintain for a long time. On the other hand, there are some study habits which are counter effective. For example, Siahi and Maiyo (2015) claim that some of the worst study habits are studying in inappropriate conditions, procrastination, and playing loud music and TV when studying.

\subsection{Related Studies}

There are several studies on the effects of study habits on students' academic achievement. For example, Bulenta, Hakana, and Aydina (2015) investigated the effects of undergraduates' study skills on academic achievement in terms of gender and department. They examined 210 undergraduate students in three different departments at the school of education. The results revealed that there is a positive correlation between study skills and academic achievement. Moreover, significant differences were seen in undergraduates' study skills with reference to departments and gender. In another research, Okado, Yoshida, and Kida (2017) investigated correlations between changes in study habits and academic results among 170 Japanese private junior high school students. They administered a questionnaire twice a year for three years, and collected results of regular and mock exams as well. They found out a high correlation between students' study habits and their academic results. Then, Illahi and Khandai (2015), studied the academic achievement and study habits of male and female college students in India. Their subjects were 410 including 193 males and 217 females. They found that positive study habits of college female students are slightly higher than the male. Furthermore, Fereydoonimoghadam and Cheraghian (2009), investigated the study habits of 150 nursing students using a questionnaire. Their survey revealed positive correlation between good study habits and students' academic achievements. However, their research did not find any significant correlation between students' study habits and their academic level, marital status, or age.

\section{Methods}

\subsection{Participants}

In total, 612 students (358 girls, and 254 boys) from six random high schools in two central counties of Chiayi and Yunlin in Taiwan participated in this study. The number is the students that filled out the questionnaire completely, as the incomplete or inappropriately-filled cases were removed from the further analysis.

\subsection{Instrument}

A 24-item multiple choice questionnaire was adopted from the Study Skill Assessment Questionnaire, which was authentically developed by University of Houston Clear Lake, Texas (2019). The unabridged questionnaire encompasses eight sections with eight items in each (64 items). However, because such a lengthy questionnaire is not applicable for high schools, the authors selected three groups of questions or constructs which they assumed were more pertinent to the present survey. These constructs were: time management \& procrastination (questions 1-8), study aids \& note-taking (questions 9-16), and organizing \& processing information (questions 17-24). The researchers also translated the original questionnaire items into Mandarin Chinese (Appendix).

\subsection{Research Question and Hypothesis}

Each individual question on the research questionnaire has been analyzed separately in this study. Thus, the following generic research question and hypothesis was used for each of the 24 items:

(n) - Is there any significant difference between female and male high school students and their study skills?

$\mathrm{H}_{0}$ (n) -There is no significant difference between female and male high school students and their study skills.

\section{Results}

\subsection{Hypothesis Testing}

A Pearson Chi-square test was applied for each of the 24 items of the questionnaire. Chi-square is used when we intend to examine the relationship between two categorical/nominal variables. Each of these variables can have two or more members. In the current study, the following categorical variables were cross-examined: 
- Groups (Girls/Boys);

- Response to questionnaire items (Never/Sometimes/Usually/Always).

Table 1 summarizes the results $(\alpha \leq .05)$.

Table 1. Summary of the Chi-square test results for each item of the questionnaire

\begin{tabular}{cccl}
\hline Item & $\begin{array}{c}\text { Pearson Chi-square } \\
\text { value }\end{array}$ & $\begin{array}{c}\text { Asymp. Sig. } \\
\text { (2-sided) }\end{array}$ & $\begin{array}{l}\text { Significant or } \\
\text { Non-significant }\end{array}$ \\
\hline 1 & 49.382 & .000 & Significant \\
2 & 1.570 & .666 & Non-sig. \\
3 & 3.885 & .274 & Non-sig. \\
4 & 2.038 & .565 & Non-sig. \\
5 & 12.054 & .007 & Significant \\
6 & 1.846 & .605 & Non-sig. \\
7 & 10.180 & .017 & Non-sig. \\
8 & 9.540 & .023 & Significant \\
9 & 4.796 & .187 & Non-sig. \\
10 & 1.163 & .762 & Non-sig. \\
11 & 3.014 & .390 & Non-sig. \\
12 & 1.774 & .621 & Non-sig. \\
13 & 2.199 & .532 & Non-sig. \\
14 & 2.369 & .499 & Non-sig. \\
15 & 3.275 & .351 & Non-sig. \\
16 & .963 & .810 & Non-sig. \\
17 & 1.873 & .599 & Non-sig. \\
18 & 3.582 & .310 & Non-sig. \\
19 & .542 & .910 & Non-sig. \\
20 & 4.368 & .224 & Non-sig. \\
21 & 1.610 & .657 & Non-sig. \\
22 & 2.038 & .565 & Non-sig. \\
23 & 1.726 & .631 & Non-sig. \\
24 & 2.454 & .484 & Non-sig. \\
\hline & & &
\end{tabular}

As can be seen, Table 1 shows that the corresponding significance level of each chi-square test has been put next to its counterpart Pearson chi-square value. In order to be significant, each Sig. value must be .05 or smaller. Thus, the results reveal that among the 24 questions of the questionnaire, just items 1,5 , and 8 have been responded significantly differently by both female and male students. It can be suggested then that for these three items the null hypotheses (There is no significant difference between female and male high school students and their study skill.) can be rejected. In other words, boys and girls have very different views towards these three study habits. On the other hand, as for the other 21 items of the questionnaire, the differences between boys and girls have not been significant, suggesting that they have very similar ideas/views regarding their study habits/skills. Thus, as for the other 21 items (other than items 1, 5, and 8), the null hypothesis cannot be rejected.

\subsection{Individual Response Cross-Examination}

As stated earlier, in the current study three main constructs of "time management \& procrastination", "study aids \& note-taking", and "organizing \& processing information" have been used. Tables 2, 3, and 4 separately list the questionnaire items in each construct with juxtaposing percentage of both gender's responses.

Table 2. Students' responses to each item on "time management $\&$ procrastination" by percentage

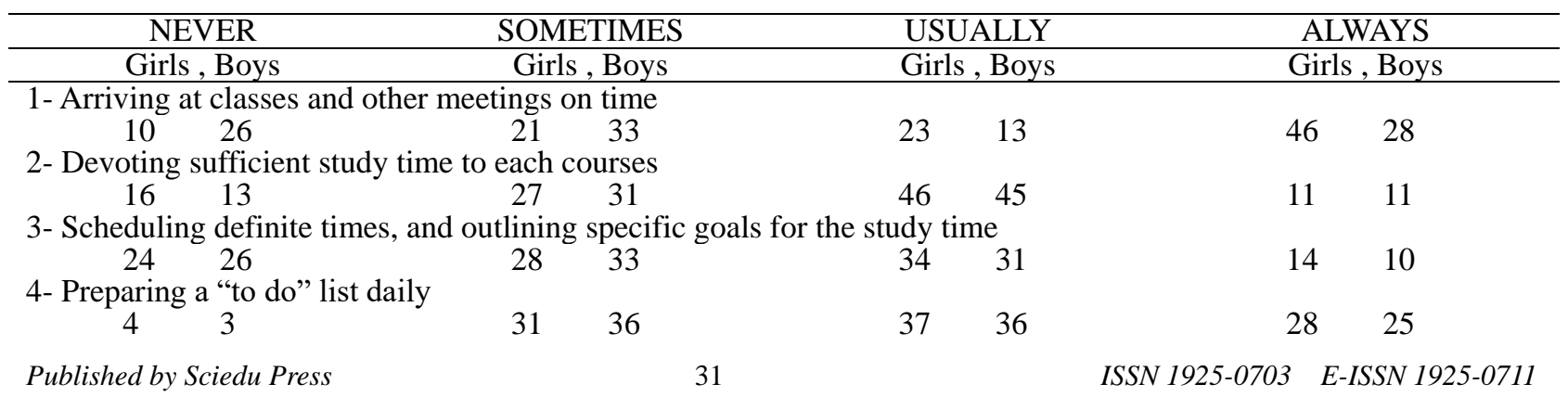


5- Avoiding activities which tend to interfere with the planned schedule
$24 \quad 16$
$25 \quad 19$
study$$
31 \quad 38
$$
$31 \quad 37$
20
$20 \quad 28$$$
13 \quad 10
$$
$31 \quad 38$
$42 \quad 40$
$14 \quad 12$
$\begin{array}{lllll}30 & 40 & 26 & 21 & 17\end{array}$
$17 \quad 21 \quad 22$
8- Beginning major course assignments well in advance $\begin{array}{llll}16 & 11 & 36 & 29\end{array}$
$31 \quad 41$
$17 \quad 19$

6- Using prime time

Table 3. Students' responses to each item on "study aids \& note-taking" by percentage

\begin{tabular}{|c|c|c|c|c|}
\hline NEVER & SOMETIMES & USUALLY & $\overline{\mathrm{ALK}}$ & AYS \\
\hline Girls, Boys & Girls, Boys & Girls, Boy & Girls & Boys \\
\hline \multicolumn{5}{|c|}{ 9- Thinking about how to use them later while taking notes } \\
\hline 7 & 3138 & 39 & 22 & 16 \\
\hline \multicolumn{5}{|c|}{ 10- Understanding the lecture and classroom discussion while taking notes } \\
\hline $23^{\circ}$ & 28 & 22 & 28 & 27 \\
\hline \multicolumn{5}{|c|}{ 11- Organizing notes in some meaningful manner (such as outline format) } \\
\hline 8 & 36 & 40 & 16 & 11 \\
\hline \multicolumn{5}{|c|}{ 12- Reviewing and editing notes systematically } \\
\hline 41 & 31 & 16 & 18 & 12 \\
\hline \multicolumn{5}{|c|}{ 13- Taking notes on supplementary reading materials } \\
\hline 13 & 33 & 45 & 12 & 11 \\
\hline \multicolumn{5}{|c|}{ 14- Having a system for marking textbooks } \\
\hline 48 & 30 & 16 & 8 & 6 \\
\hline \multicolumn{5}{|c|}{ 15- Marking or underlining important parts when reading } \\
\hline 10 & 36 & 43 & 18 & 13 \\
\hline \multicolumn{5}{|c|}{ 16- Writing notes in the book while reading } \\
\hline 38 & 25 & 33 & 7 & 8 \\
\hline
\end{tabular}

Table 4. Students' responses to each item on "organizing \& processing information" by percentage

\begin{tabular}{|c|c|c|c|c|c|}
\hline NEVER & SOMETIMES & & ALLY & & IAYS \\
\hline Girls, Boys & Girls, Boys & & Boys & Gil & Boys \\
\hline 17- Distinguish read & oortant and unim & whe & eading & & \\
\hline 19 & 27 & 25 & 25 & 33 & 29 \\
\hline 18- Breaking assignn & ageable parts & & & & \\
\hline 4 & $28 \quad 35$ & & 36 & 28 & 25 \\
\hline 19- Maintaining a cri & uring study - thil & cep & or rejecting & & \\
\hline $45 \quad 43$ & 31 & 15 & 16 & 11 & 10 \\
\hline 20- Relating materia & course to mater & ourse & & & \\
\hline 106 & 42 & 45 & 44 & 9 & 8 \\
\hline 21- Trying to organiz & tematic way & & & & \\
\hline 39 & 27 & 23 & 25 & 12 & 9 \\
\hline 22- Using questions & ze and understar & whe & tudying & & \\
\hline 4 & 36 & 37 & 36 & 28 & 25 \\
\hline 23- Trying to find th & o do a given job & & & & \\
\hline 32 & 36 & 26 & 24 & 9 & 8 \\
\hline 24- Solving a proble & on its main poin & & & & \\
\hline 13 & 16 & 32 & 38 & 36 & 33 \\
\hline
\end{tabular}

\subsection{Variability Measurement}

Statistically, SPSS does not offer us the direction of the differences because we are working with nominal/categorical data here. Nonetheless, the researchers have measured all the differences (even though they have been mostly trivial or even nil). This was possible because the University of Houston Clear Lake, Texas (the developer of the source questionnaire) has also provided us with a set of grading rubrics. This rubric relates mathematical values to the questionnaire choices as follows: Never $=1$; Sometimes $=2$; Usually $=3$; and Always $=4$. It is interesting to notice that there is controversy as to the validity of using parametric analysis with Likert scale data. Some scholars emphasize that the intervals between the Likert scales are not equal; and thus, any numerical values applied to them are invalid (Jamieson, 2004). On the other hand, there are some advocates who approve applying parametric tests (Lubke \& Muthen, 2004). The reason might be that although the intervals in Likert scales are not equal mathematically, when used equally between groups, the results can be, at least to some extent, indicative of potential variations/similarities. 
The present study, then, tilts towards the second group.

The original rubric focusses on the sum of each construct (consisting of eight items each). These are the values as well as the approximate suggested interpretations: total $>28$ (high); total 21-28 (intermediate and high-intermediate); total 20 or less (low). Thus, if we calculate the average of these values for the whole sample of the study, we can have the approximation for each individual item of the questionnaire (a certain study habit/skill) as follows: total $>3.5$ (high); total 2.6-3.5 (intermediate and high-intermediate); total 2.5 or less (low). Consequently, and based on the grading rubrics mentioned, the researchers have calculated the mathematical values of each individual response to the questions. Table 5 illustrates the findings below.

Table 5. Results after applying the rubrics for each question

\begin{tabular}{|c|c|c|c|c|c|c|c|c|c|c|c|c|c|c|}
\hline \multicolumn{5}{|c|}{$\begin{array}{c}\text { Time Management \& } \\
\text { Procrastination }\end{array}$} & \multicolumn{5}{|c|}{ Study Aids \& Note-taking } & \multicolumn{5}{|c|}{$\begin{array}{c}\text { Organizing \& Processing } \\
\text { Information }\end{array}$} \\
\hline $\mathrm{Q}$ & G & B & Diff & Result & $\mathrm{Q}$ & $\mathrm{G}$ & B & Diff & Result & $\mathrm{Q}$ & $\mathrm{G}$ & $\mathrm{B}$ & Diff & Result \\
\hline & Ave & Ave & & & & Ave & Ave & & & & Ave & Ave & & \\
\hline 1 & 3.05 & 2.44 & .61 & $\mathrm{G}>\mathrm{B}$ & 9 & 2.76 & 2.64 & .12 & $\mathrm{G}>\mathrm{B}$ & 17 & 2.75 & 2.63 & .12 & $\mathrm{G}>\mathrm{B}$ \\
\hline 2 & 2.52 & 2.55 & -.03 & $\mathrm{~B}>\mathrm{G}$ & 10 & 2.56 & 2.50 & .06 & $\mathrm{G}>\mathrm{B}$ & 18 & 2.85 & 2.81 & .04 & $\mathrm{G}>\mathrm{B}$ \\
\hline 3 & 2.37 & 2.24 & .13 & $\mathrm{G}>\mathrm{B}$ & 11 & 2.63 & 2.55 & .08 & $\mathrm{G}>\mathrm{B}$ & 19 & 1.91 & 1.91 & 0 & $\mathrm{G}=\mathrm{B}$ \\
\hline 4 & 2.88 & 2.82 & .06 & $\mathrm{G}>\mathrm{B}$ & 12 & 2.07 & 1.99 & .08 & $\mathrm{G}>\mathrm{B}$ & 20 & 2.52 & 2.51 & .01 & $G>B$ \\
\hline 5 & 2.47 & 2.76 & -.29 & $\mathrm{~B}>\mathrm{G}$ & 13 & 2.50 & 2.55 & -.05 & $\mathrm{~B}>\mathrm{G}$ & 21 & 2.09 & 2.03 & .06 & $G>B$ \\
\hline 6 & 2.56 & 2.55 & .01 & $G>B$ & 14 & 1.86 & 1.76 & .10 & $G>B$ & 22 & 2.88 & 2.82 & .06 & $\mathrm{G}>\mathrm{B}$ \\
\hline 7 & 2.34 & 2.21 & .13 & $G>B$ & 15 & 2.64 & 2.62 & .02 & $G>B$ & 23 & 2.17 & 2.07 & .10 & $\mathrm{G}>\mathrm{B}$ \\
\hline 8 & 2.48 & 2.66 & -.18 & $B>G$ & 16 & 2.11 & 2.09 & .02 & $G>B$ & 24 & 2.87 & 2.91 & -.04 & $\mathrm{~B}>\mathrm{G}$ \\
\hline
\end{tabular}

Note: Ave=average; $\mathrm{B}=$ boys'; $\mathrm{G}=$ girls'; Diff =average difference; $\mathrm{Q}=$ question

\section{Discussion}

The current paper revealed that Taiwanese high school boys and girls have very few significant differences with respect to study habits/skills. Based on Table 5, the major differences observed in the data were items 1, 5, and 8 . Item 1 (arriving at classes and other meetings on time) has the biggest mean difference of .61 among all the items of the questionnaire. Based on the responses to this question, it seems that Taiwanese high school girls, compared with the boys, pay a lot more attention to punctuality in attending their classes. On the contrary, the lowest difference was 0 for item 19 (maintaining a critical attitude during study - thinking before accepting or rejecting). This item also received the mean of 1.91 which is the second lowest in all the questions. This means that both high school boys and girls should be more concerned about this very study habit. Then, boys seem to be more efficient in item 5 (avoiding activities which tend to interfere with the planned schedule), and item 8 (beginning major course assignments well in advance). On average, boys scored .29 and .18 higher than the girls for these two study habits respectively. On the other hand, both genders seem to have the lowest mean of 1.86, and 1.76 for item 14 (having a system for marking textbooks). Students need to relook at this study habit and try to find ways to master this useful skill. Furthermore, and based on Table 5 and the rubric guidelines (and having in mind that it was originally developed and suggested for university students), we can deduce that except for items 14 and 19, both Taiwanese female and male students almost equally have intermediate and high-intermediate study habits.

The findings of this study, thus, cannot fully confirm the study done by Bulenta, Hakana, and Aydina (2015). Neither can they comply with the results of, Illahi and Khandai (2015)'s study in which positive study habits of female students were proven to be slightly higher than the males.

\section{Conclusion}

The present topic is of significant educational importance. It can inspire students to change their weak study habits, and strengthen their already good ones. Given the pace of life today, the authors assert that high school students need to be encouraged to use library books and reading materials more. This does not mean disregarding the new 
technology such as Internet apps. We believe it to be self-evident that if used properly, advanced technological aids can be exploited in order to develop good study habits. In this regard, the learners might need more counselling and advice from their peers and teachers to build up better study habits and avoid distractive behaviors.

\section{References}

Aquino, L. B. (2011). Study habits and attitudes of freshmen students: Implications for academic intervention programs. Journal of Language Teaching and Research, 2(5), 1116-1121. https://doi.org/10.4304/jltr.2.5.1116-1121

Bajwa, N., Gujjar, A. A., Shaheen, G., \& Ramzan, M. (2011). A comparative study of the study habits of the students from formal and non-formal systems of education in Pakistan. International Journal of Business and Social Science, 2(14), 175-186.

Bulenta, A., Hakana, K., \& Aydina, B. (2015). An analysis of undergraduates' study skills. Procedia - Social and Behavioral Sciences, 197(2015), 1355-1362. https://doi.org/10.1016/j.sbspro.2015.07.389

Ebele, U. F., \& Olofu, P. A. (2017). Study habit and its impact on secondary school students' academic performance in biology in the Federal Capital Territory, Abuja. Educational Research and Reviews, 12(10), 583-588. https://doi.org/10.5897/ERR2016.3117

Fereydoonimoghadam, M., \& Cheraghian, B. (2009). Study habits and its relation to academic performance in Abadan nursing students. Strides in Development of Medical Education, 6(1), 21-28.

Gettinger, M., \& Siebert, J. K. (2002). Contributions of study skills to academic competence. School Psychology Review, 31(3), 351-365. Retrieved from https://www.tandfonline.com/doi/abs/10.1080/02796015.2002.12086160

Grohol, J. M. (2018). 10 highly effective study habits. Psych Central. Retrieved from https://psychcentral.com/lib/top-10-most-effective-study-habits/

Illahi, B. Y., \& Khandai, H. (2015). Academic achievements and study habits of college students of District Pulwama. Journal of Education and Practice, 6(13), 1-6.

Issa, A. O., Aliyu, M. B., Akangbe, R. B., \&Adedeji, A. F. (2012). Reading interest and habits of the Federal Polytechnic OFFA students. International Journal of Learning \& Development, 2(1), 470-486. https://doi.org/10.5296/ijld.v2i1.1470

Jamieson, S. (2004). Likert scales: how to (ab) use them. Medical Education, 38, 1212-1218. https://doi.org/10.1111/j.1365-2929.2004.02012.x

Jansen, E. P. W. A., \& Suhre, C. J. M. (2010). The effect of secondary school study skills preparation on first-year university achievement. Educational Studies, 36(5), 569-580. https://doi.org/10.1080/03055691003729070

Lubke, G. H., \& Muthen, B. O. (2004). Applying Multigroup Confirmatory Factor Models for Continuous Outcomes to Likert Scale Data Complicates Meaningful Group Comparisons. Structural Equation Modeling, 11, 514-534. https://doi.org/10.1207/s15328007sem1104_2

Neri, D. L. E. (2007). Learning styles and study skills among nursing students. Liceo Journal of Higher Education Research, 5(1), 97-109. https://doi.org/10.7828/ljher.v5i1.7

Ogbodo, R. O. (2010). Effective study habits in educational sector: Counseling implications. Edo Journal of Counseling, 3(2), 230-242. https://doi.org/10.4314/ejc.v3i2.63610

Okado, K., Yoshida, H., \& Kida, N. (2017). Correlations between changes in study habits and academic results in junior high school students - a longitudinal survey at a private junior high school. Psychology, 08(13), 2102-2113. https://doi.org/10.4236/psych.2017.813133

Palani, K. K. (2012). Promising reading habits and creating literate social. International Reference Research Journal, 3(2), 90 .

Purdue, N., \& Hattie, J. (1999). The relationship between study skills and learning outcomes: A meta-analysis. Australian Journal of Education, 43(1), 72-86. https://doi.org/10.1177/000494419904300106

Putwain, D., Sander, P., \& Larkin, D. (2013). Academic self-efficacy in study-related skills and behaviors: Relations with learning-related emotions and academic success. British Journal of Educational Psychology, 83(4), 633-650. https://doi.org/10.1111/j.2044-8279.2012.02084.x 
Scott, S. J. (2019). 11 good study habits to better understand your lessons. Old-time Publishing LLC. Retrieved from https://www.developgoodhabits.com/good-study-routine/

Siahi, E. A., \& Maiyo, J. K. (2015). Study of the relationship between study habits and academic achievement of students: a case of Spicer Higher Secondary School, India. International Journal of Educational Administration and Policy Studies, 7(7), 134-141. https://doi.org/10.5897/IJEAPS2015.0404

Smith, C. C. (2018). Good study habits. Students Disability Services. Retrieved from https://www.cmich.edu/ess/studentaffairs/SDS/Pages/10-Habits-10-Traps.aspx

Steele, M. M. (2010). High school students with learning disabilities: Mathematics instruction, study skills and high stakes tests. American Secondary Education, 38(3), 21-27. Retrieved from https://eric.ed.gov/?id=EJ904931

Study Skill Assessment Questionnaire. (2019). Department of Counseling Services, University of Houston Clear Lake, Texas. Retrieved from https://www.uhcl.edu/counselingservices

Wagner, P., Schober, B., \& Spiel, C. (2008). Time investment and time management: An analysis of time students spend working at home for school. Educational Research and Evaluation, 14(2), 139-153. https://doi.org/10.1080/13803610801956606

Yu, D. D. (2011). How much do study habits, skills and attitudes affect student performance in introductory college accounting courses? New Horizons in Education, 59(3), 1-15.

\section{Appendix: The Questionnaire (Chinese Version)}

性別: $\square$ 男 $\square$ 女

\section{學習技巧評量問卷}

此問卷目的是要讓我們了解您的學術技能以及讓我們瞭解您是如何看待這些技巧。您的作答是我們 寶貴的資訊, 敬請誠實作答。非常感謝您的配合。

1- 我會準時出席課程或其他會議。
從不如此
有時如此
經常如此
總是如此

2- 我對於每一門課都投入相當充足的學習時間。
從不如此
有時如此
經常如此
總是如此

3- 我會明確的規劃讀書時間與設定具體的學習目標。
從不如此
有時如此
經常如此
總是如此

4- 我每天都會準備一張「待辦事項」表。
從不如此
有時如此
經常如此
總是如此

5- 我會避免會干擾到我的計劃的活動。

從不如此 $\square$ 有時如此

經常如此

總是如此

6- 我會使用最好的時機專注讀書。 

從不如此
有時如此
經常如此
總是如此

7- 我會在學期初制定日常活動與學習計畫表。
從不如此
有時如此
經常如此
總是如此

8- 我會提早準備主要科目的作業。
從不如此
有時如此
經常如此
總是如此

9- 當我做筆記時, 我會想待會要怎麼應用它們。
從不如此
有時如此
經常如此
總是如此

10- 當我做筆記時, 我了解老師的講課與課堂討論。
從不如此
有時如此
經常如此
總是如此

11- 我會用有意義的方法來組織我的筆記。(例如: 大綱格式)
從不如此
有時如此
經常如此
總是如此

12- 我有組織地複習與編輯我的筆記。
從不如此
有時如此
經常如此
總是如此

13- 我會在補充的閱讀資料上做筆記。
從不如此
有時如此
經常如此
總是如此

14- 我有一套畫重點的方法。
從不如此
有時如此
經常如此
總是如此

15- 閱讀時, 我會把我認為重要的部分作記號或畫底線。
從不如此
有時如此
經常如此
總是如此

16- 當我閱讀時, 我會在書上寫筆記。
從不如此
有時如此
經常如此
總是如此

17- 閱讀時, 我可以很輕易地分辨重要與不重要的部分。
從不如此
有時如此
經常如此
總是如此

18- 我會把作業拆成幾個比較好處理的部分。 
$\square$ 從不如此

有時如此

經常如此

總是如此

19- 在思考接受與否前, 我會保持嚴謹的態度。

從不如此

有時如此

經常如此

總是如此

20- 我會將已經學習過的內容連結於別的課程中。
從不如此
有時如此
經常如此
總是如此

21- 我會嘗試用有系統的方式組織學過的知識。
從不如此
有時如此
經常如此
總是如此

22- 我會用問題來組織與了解我正在閱讀的題材。
從不如此
有時如此
經常如此
總是如此

23- 我會嘗試找到最好的方法來做被交代的工作。
$\square$ 從不如此
有時如此
經常如此
總是如此

24- 我會透過聚焦在事情的重點來解決問題。
從不如此
有時如此
經常如此
總是如此

\section{作答結束}

